\title{
Things and Trauma in Joe Sacco's Safe Area Goražde
}

\author{
Shalini Deepa Srinivasan \\ PhD Candidate, Dept. Of English, University of Hyderabad. Orcid.org/oooo-ooo1-5744- \\ 951X. Email: shalinisrinivasan@gmail.com
}

Received May 01, 2017; Revised November 13, 2017; Accepted November 30, 2017; Published December o9, 2017.

\begin{abstract}
In Joe Sacco's Safe Area Goražde readers find a representational strategy that relies upon dense imagery, teeming with everyday things. In the wake of trauma, things accrue meaning: they generate means of identity, they are invested with emotional and cultural values, and they perform history and space, becoming what Janet Hoskins terms "biographical objects". War trauma ruptures temporality and narrative, symbolised by the barricade that separates Goražde from the rest of the world, holding it in stasis. This essay argues that two categories of things in Safe Area Goražde come to mediate the effects of trauma: articles of wear, which are imbued with individual identity, and future-oriented; and homes which acquire repositorial significance, tying together familial pasts and futures. Both act as containers of bodies and families, reifying the subject, and gesturing towards a post-traumatic future.
\end{abstract}

Keywords: comics, trauma, everyday, things, clothes

\section{Introduction: Talking of Things}

The very first speech bubble in Safe Area Goražde sets the terms for what is to come, as Sacco's friend and guide-translator Edin says, "I think things will get much better" (2000, p. 1). And it is Edin and things that also end the comic, with Sacco observing, "He wanted to get on with things" (p. 227). Things are crucial to the construction and maintenance of the safe area: the ceasefire of 1995 mandates opening the road between Goražde and Sarajevo. As convoys of goods lorries finally begin to enter the town, they carry with them food, medical supplies, and clothing, heralding the eventual end of the war and creating an instant lightening of the mood (p. 6o). One woman describes the situation thus: "Things have improved," she says, and then "I have enjoyed every little thing" and again, "I'll never complain about anything again (p. 6o)." Things, for her, encompass not only the (now cheaper) cigarettes and coffee she enjoys, but also, metonymically, come to stand for her situation as a whole., and we see this in the way that this woman's everyday life, her environment, and her physical and emotional selves, can be spoken for by things.

Christopher Tilley remarks in an essay called "Objectification" that "Personal, social and cultural identity is embodied in our persons and objectified in our things" (2006, p. 61). But are clothes and houses objectifications of identity, or are they something more intimate that both embody and mediate how our bodies interact with the outside world? Objectification, in this sense, allows this woman and Edin to speak of potentially traumatic personal details, impersonally. Sacco notes that, "Perhaps the greatest of the new joys arriving with the convoys were private parcels - the first received since the beginning of the war" (p. 61). New things signal

(c) AesthetixMS 2016. This Open Access article is published under a Creative Commons Attribution Non-Commercial 4.0 International License (http://creativecommons.org/licenses/by-nc/4.o/), which permits non-commercial re-use, distribution, and reproduction in any medium, provided the original work is properly cited. For citation use the DOI. For commercial re-use, please contact editor@rupkatha.com. 
hope, for the end of the war is signalled not by the free movement of people through the blockade - it will be some time before than can happen - but by the free movement of things.

Sacco lays out the purpose of Safe Area Goražde: finding the Real Truth (p. 1, p. 2, p. 151) of the Bosnian War. The comic develops through interviews with the people of Goražde as they wait for the restoration of normalcy. The testimonies of survivors, witnesses, combatants, and their friends and family, mediated by Sacco, create a complex narrative that depicts the horrors of the conflict. Safe Area Goražde is dense - verbally and pictorially - with the things of everyday life. Sacco's narrative pays great attention to the everyday, the mundane - eating, drinking, smoking, getting firewood. This sense of fullness and detail as truth is a repeated motif in most critical treatments of Sacco's work. Jeff Adams remarks on Sacco's “detailed etched finish" and "extensive narration texts" (2006, p. 173), while Andrea Lunsford and Adam Rosenblatt comment that "Sometimes he zooms in so close that we feel as if we have invaded the personal space of his interviewee" (2011, p. 137). In a presentation, Sacco himself describes an attempt to make his art "loud" (2004, unpaginated.). Many of the individual testimonies in the comic have, at their centre, quotidian concerns - getting food, for example (Sacco, 200o, p. 135-147). Rose Brister, in her analysis of Sacco's earlier Palestine, equates Sacco's search for the "essential truth" of a situation with "a people's everyday life" (2014, p. 105). Sacco's Real Truth, in other words, lies in the plenitude and density of information, especially everyday details.

Two categories of things that feature prominently in Safe Area Goražde will be analysed here: clothing (and objects of personal wear) and houses. Objects of wear, I argue, come to stand in for individual identity, but also, due to their aspirational status, become links to the future. Houses come to stand for both individual and communal identity, and their role as depositories makes them a link between the pre-traumatic past, and a hopeful future.

The theme of trauma will be woven through the analyses, read in Luckhurst's terms as a "tangled object" that in theory and practice functions to "mess up our fundamental categories of subject and object" (2008, p. 14). Luckhurst notes that notions of trauma are "stalled somewhere between the physical and the psychical" (p. 3), and "anti-narrative" (p. 79), suggesting that some of its effects are temporal. The final section will deal with the implications of this, suggesting that things may function to traverse the temporal blockages created by trauma.

\section{Clothing}

In The Meaning of Things Mihaly Csikszentmihalyi and Eugene Rochberg-Halton list clothing first in their catalogue of the personal possessions that are most closely aligned with identity: "Not surprisingly, the clothes one wears, the car one drives, and the furnishings of one's home, all are expressions of one's self even when they act as disguises rather than reflections" (1981, p. 14-15). The link between clothes and identity in Sacco's work is established and explored in numerous instances. At a fundamental level, clothes identify people, standing for them even after death: in one instance, seven corpses are found decomposed in a grave, two of them Edin's friends: "We recognized them mainly from their clothes" (2000, p. 92).

That clothes have special significance among things is soon apparent. Sacco's friend Edin is a teacher whose school gets orange boots from the UNHCR for the students. The boots are "derided" as "cheapo" (p. 188) and called "orange monstrosities" (p. 189). Margreta de Grazia, in her reading of King Lear, describes clothing as the one "superfluous possession" that all human beings have, an ownership that unites all humans and (1996, p. 22-3). Edin has lost his home, and 
his freedom of movement; boots are among the few possessions he owns that are wholly his, and he must depend upon the UN for them. If clothing constitutes people, then the boots' monstrousness is significant, beyond their utilitarian role: Edin hopes that the teachers will get better boots (p. 189).

As with Edin's boots, new clothing may become aspirational. When private parcels start to come through the barricades in Goražde, many people write to friends and relatives outside the blockade, asking for new clothes. "The young women censoring the letters were bored to tears reading all the outgoing requests," Sacco says (2000, p. 61). One of the young women notes that all the letters follow the same pattern: “'I want trousers, I want shoes, here are my sizes" Every letter the same" (p. 61). On one occasion, Sacco leaves Goražde and is requested to bring "perfumes and shoe polish and lipsticks and playing cards," a watch ("a cheap one," the girl requests), and toiletries "hair color, facial cream, something for skin allergies" (p. 62). Many of these things are small luxuries, but they are also a part of everyday life - soothing allergies, dressing up, keeping time, playing games. Many of Sacco's women friends ask him to bring them back Levi's jeans, mementoes of a world outside that they, imprisoned within their tiny "safe area," no longer have access to (p. 7, p. 56). Edin - ironically, given his opinion on his own boots suggests that books rather than jeans would be a "better" thing to request, adding, "wouldn't that show more character?" (p. 56). The narrative agrees, using the phrase "of course" and terming the women "silly girls" (ibid.). Edin's remark allows that things are important to identity, but seems to affirm an already-existing hierarchy of things, where books are placed above clothing, reifying what Gail Weiss has characterised as "the longstanding association of the mind with transcendence and the body with immanence" (1999, p. 4).

Sacco's work complicates and challenges this dichotomy, emphasising the thingness of books and the transformative power of clothing. That clothing is not "silly" is signalled by its recurrence across Safe Area Goražde, each time accruing more nuance. In a chapter titled "Silly Girls Pt. III", Sacco returns to Goražde and delivers to Sabina (one of the girls of the title) a package from relatives in Sarajevo, saying: “... she'd been very specific about what sort of jeans they should send - the labels said 501's but -" Sure enough Sabina notices that they are not quite what she wants, that "They're not originals!" (2000, p. 193). On another occasion, Sacco returns to Goražde with "lipsticks and letters" (p. 67), things of both individual and social value. The juxtaposition here echoes Belinda's dressing-table from "The Rape of the Locki," another work which displays what Stewart Crehan terms a "fascination with man-made objects in which the observing self appears flatteringly refashioned" (1997, p. 54). In other words, lipstick and perfume are tools of self-composition, that also play into the way this self is perceived by others. Sacco's "loudness" is in full effect: for despite the narrative voice's bland agreement, Edin's hierarchy of things is being challenged within the text, by other voices such as Sabina's.

Susan Pearce notes that, "Objects are important to people because they demonstrate prestige and social position" (1994, p. 131), and Sabina echoes her: "They fit well enough ..." but to Sabina the fact that they are not American means a loss of prestige, for, as she says, "Everyone will know they're not originals" (2000, p. 193). She briefly considers wearing them with a long coat so no one can see the label, but her friend Nudjejma says, "That won't do any good. They're obviously European" (p. 193).

Csikszentmihalyi and Rochberg-Halton note that status symbols are marks of authority (1981, p. 59). De Grazia's reading agrees that owning such an object comes to mean having the "power to control others" and is "a global measure of the owner's standing in the community" (1996, p. 31). Sabina, Nudjejma, and all the other women who want to buy lipstick and face 
creams, perfume and shoes are not silly as the chapter's title suggests - instead, they are deeply aware of the fact that their clothes and their physical appearances constitute them, not only to others, but also to themselves. In blockaded Goražde, having access to jeans, lipsticks, and watches confers a certain cachet upon the wearer. While these objects certainly do contribute to social position, and the relationships that go towards maintaining it, they do not simply demonstrate social position. There is another element to this, as Janet Hoskins notes:

"It is perhaps significant that the "biographical objects" my informants selected were often containers (the betel pouch, the hollow drum, the funeral shroud), which served as "memory boxes" for holding certain things inside or (in the case of the green bottle) creating anxiety about their capacity to escape." (1998, p. 5)

Clothing is of course, in its fundamental sense, a container for the self, a way of bounding and delimiting the body from its immediate environment, mediating interactions.

As aspirational things, clothes acquire a temporal component, and may come to signify power not only over others, but over one's self - a power that acquires significance in the wake of war and loss. When the blockades are fully removed a woman named Lejla moves to Sarajevo. The panel where she describes her new life juxtaposes the narrative voice with Lejla's. The caption says, "... even war-weary and shabby Sarajevo seemed a place full of life and possibility"; Lejla's speech bubble says, "I go into a store and I want to buy everything ..." (Sacco, p. 225). This paralleling of hope and buying things indicates that the narrative voice has evolved from its earlier stance on clothing to acknowledging its importance as a tool of self-construction.

Though clothes might pass for, to use another of Hoskins' phrases, "surrogate selves" (Hoskins, 1998, p. 8), especially in a comic where the outlines of clothes become the spatial representation of bodies (see Fig. 1), they are easily changed, removed, torn, and muddied. Sacco's comics, though, do focus on another kind of container, one that is more temporally and spatially durable than clothes: the house.

\section{Houses}

If articles of wear (clothes, cosmetics, and shoes) are used to perform mostly individual identity and status, and are therefore aspirational and future-oriented, household objects, in contrast, are tied closely to the family, to the safety and security of the pre-traumatic past - and allow it to be accessed while bypassing the individual trauma the subject has endured. Joe Moran observes that of all the everyday places of work and routine, only houses are romanticised, and "instead of being dismissed as residual, they have been desired and meaningful objects" (2005, p. 130). In Sacco, the damage done to homes - bullets, bombs, vandalization - thus becomes a source of great anxiety, as it invokes the traumatic war into the temporal structure that defines the subject's past and future. In an essay on Sacco's Palestine, Jeff Adams describes the connections between homes and the interior lives of their inhabitants (2006, p. 170), characterizing the domestic spaces in that comic as fraught by "the ever-present threat of violence" (2006, p. 168), rendering them "sites of anxiety and psychosis (p. 169).

In Safe Area Goražde, this threat lurks mostly unspoken in the barricaded area, which is filled with people who have already been displaced and are always aware of the fragility of their current homes and the barricade, and of the war raging outside. When the first convoys start to come through the blockade bringing food supplies, a sixteen-year-old named Nudjejma invites home a group of people including Sacco and Edin, offering them a banana cake she's made 
(Sacco, 2000, p. 50). Her toothy grin and geniality slowly fall away to reveal her true motive for filling her home with food and people - she is anxious. "I'm worried about the spring," she says (p. 53). Njudjema's anxieties revolve around home: her family's original home was burnt down; another time, "she came home, found the front door blasted through by shrapnel, her parents bleeding inside..." (2000, p. 53). Though her parents have recovered and they have found a new home, Njudjema is haunted by the first two acts of violence, and the possibility of this home's destruction. Uttering this last anxiety, Njudjema goes silent. Her face is now drawn against a plain black background, fingers fumbling. "I need a cigarette," she concludes (p. 54). With homes and families - once-stable adjuncts to her identity - revealed as impermanent and threatened Njudjema's anxieties seem to find some assuage in conversation, food, and cigarettes, things that have always been spatially and temporally ephemeral, but that help her build a sense of community.

Stories of attacks in Sacco's works are often stories of attacks upon homes: Edin relates his experiences in the Serbian attack in '94, and ends with a description of returning home in the aftermath - "I found their literature, food, shirts, cigarettes, hand grenades, bullets ... They'd slept upstairs .... the toilet was destroyed with shit everywhere .... They used my room like a toilet ..." (Fig. 1). The addition of literature emphasises the political and partisan nature of writing, and gestures towards its own thingness. Juxtaposing grenades and bullets with books, food, and excreta makes the attack deeply personal, private almost, drawing attention to the fact that the war is embedded - like the bullet holes riddling Edin's walls - in everyday life.

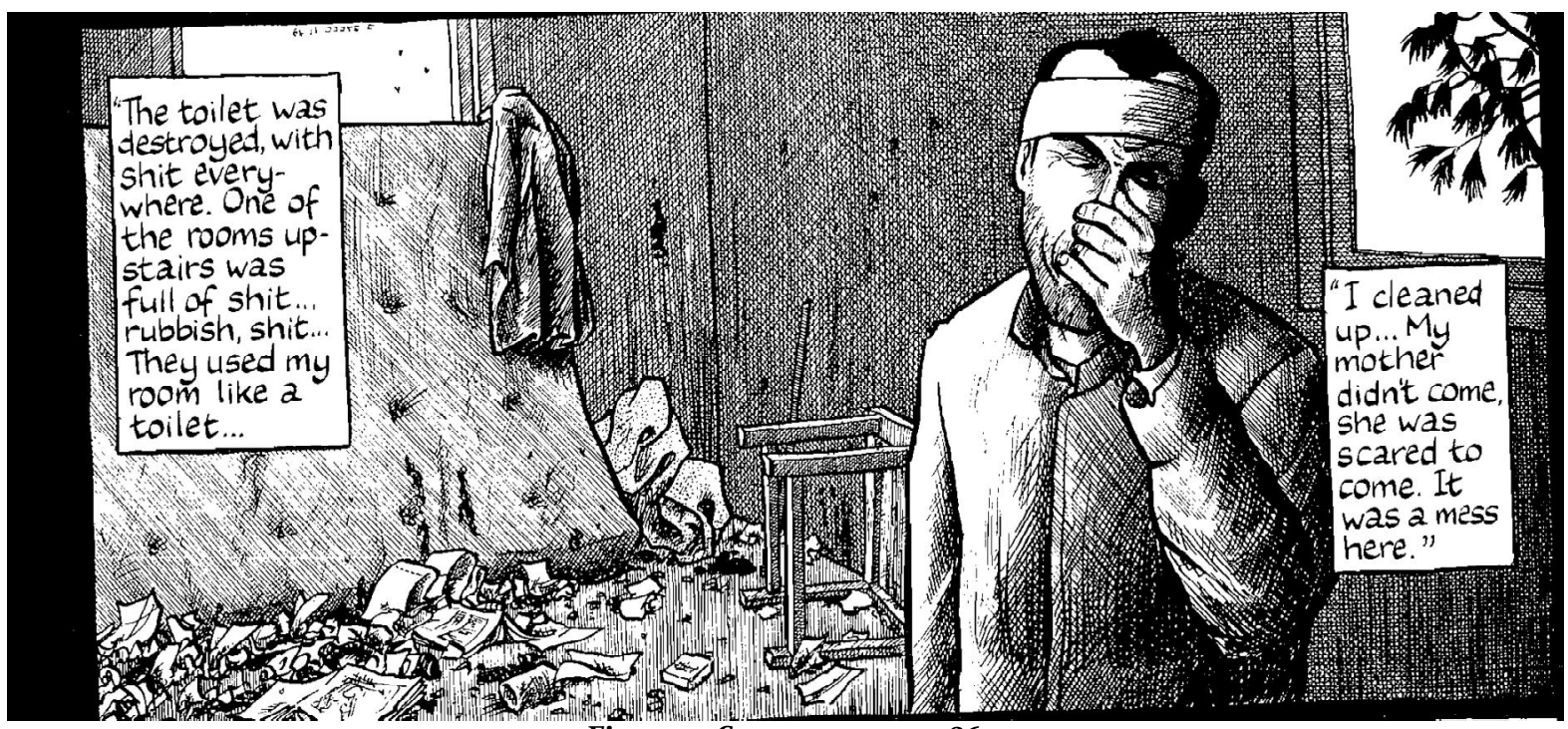

Figure 1: Sacco, 2000, p. 186

Edin's closed eyes and covered nose mark his refusal or inability to see and smell the state of his home. His jacket is shaded and textured to match the wall behind him; his old clothes hang empty and torn. Edin's head injury is mirrored in the destruction of part of his roof. House, clothes, and inhabitant, thing and person echo off each other, telling different parts of the same tale, acting as records of each other's experiences. Joe Moran notes in an essay on "Houses, Habit and Memory" that houses "represent continuity and permanence: they often outlive us" (2006, p. 33), and it is precisely the war-borne knowledge of the house's fragility, the knowledge that they might well outlast their home, that destabilises Edin and frightens (Fig. 1) his mother.

In "Talking Forks: Fiction and the Inner Life of Objects," Charles Baxter observes that "People in a traumatized state tend to love their furniture. They become ferociously attached to 
knickknacks" (1997, p. 73). Edin's subsequent behaviour demonstrates this, as he finds himself "losing time" searching desperately for a missing television (Sacco, 2000, p. 89). Edin gives up, and returns home to help rebuild it - leading to another search for their missing door (2000, p. 90). It is as if he is directionless, not quite himself, until he manages to get all the familiar objects he was invested in back inside the house. Further, Edin's remark that he's "losing time" looking for these things (p. 89) - and the subsequent revelation that his brother too has been spending the same time finding "skis and fishing rods" (p. 90) - suggests that there is a temporal aspect to what has been invested in these things, calling to mind Hoskins' characterization of biographical objects as those whose relationships to their subjects accrue meaning and change with time. The range of objects also indicates the importance of the home itself, arranged and stocked just so, with specific things in occupation of specific spaces, rebuilt to take on a form of permanence. In wartime Safe Area Goražde, we may add clothes (especially jeans) to houses, in the list of things that are romanticised by their association with a pre- or post-traumatic normality.

In Safe Area Goražde, homes, we can say, generate means of identity, they are invested with emotional and cultural values, and they perform history and space. Homes acquire special biographical significance, for they tie together the past, the present and the future, and act as repositories of the various articles of identity and tools of communication, often coming - as in the case of Edin - to stand for the subject's temporal durability.

\section{Conclusions: Things and Trauma}

Part of the premium attached to construction and mass-produced clothing may be inferred to lie in the material effects of the war, that render once-modern Goražde "strangely pre-industrial" from the loss of its electricity supply and its economic base as "... chemical, cement, and heavy machinery plants had been destroyed ... and a textile factory was a ruin housing refugees" (p. 47). This atmosphere of economic privation and of being out of step with time, "shut out" and "stewed in its own juices" (p. 72) is emphasised by the fact that cigarettes (temporary objects) have become currency: Edin is paid in them (p. 188).

But Sacco is not only asked to bring things into Goražde - he also takes them out, delivering baby clothes from grandparents, for "the granddaughter they'd never seen" (p. 63). Though they haven't met, the gift of clothes allows the grandparents to build a relationship with their granddaughter. In the "pre-industrial" barricaded world, clothes become potent gifts: they are portable, and have economic value, and are what Jones and Stallybrass describe as "material memory systems" (2000, p 34). The gift of clothes is tangible, an act of keeping in touch, a material substitute for the more intimate kinds of contact that the blockade prevents.

In Goražde, clothes take on another role: Daniel Miller and Sophie Woodward find in their study that jeans are especially associated with an idealisation of normality that they term the Goldilocks phenomenon (p. 6o), noting that, "many people are keen to buy jeans they regard as "classic", "standard", or just "normal" - that is, "just right" (Ibid). In other words, jeans stand for an unremarkable, uneventful, "ordinary" life and to the war-weary people in Goražde, that makes them deeply covetable and aspirational. Other "normal" things are also valued. In one instance, a "silly" girl (Sacco, 2000, p. 150) named Kimeta throws a party. Her family has already lost one home to the war; their new one is described ironically as "only half-gutted" (p. 150). One of the group, Riki, sings American songs, and he and the women play at "MTVing Riki" (p. 150), focusing on an everyday that is removed from the war both spatially and temporally - Riki's music is not only American, it's also mostly from the '6os and '7os - built around food, music, and community. 


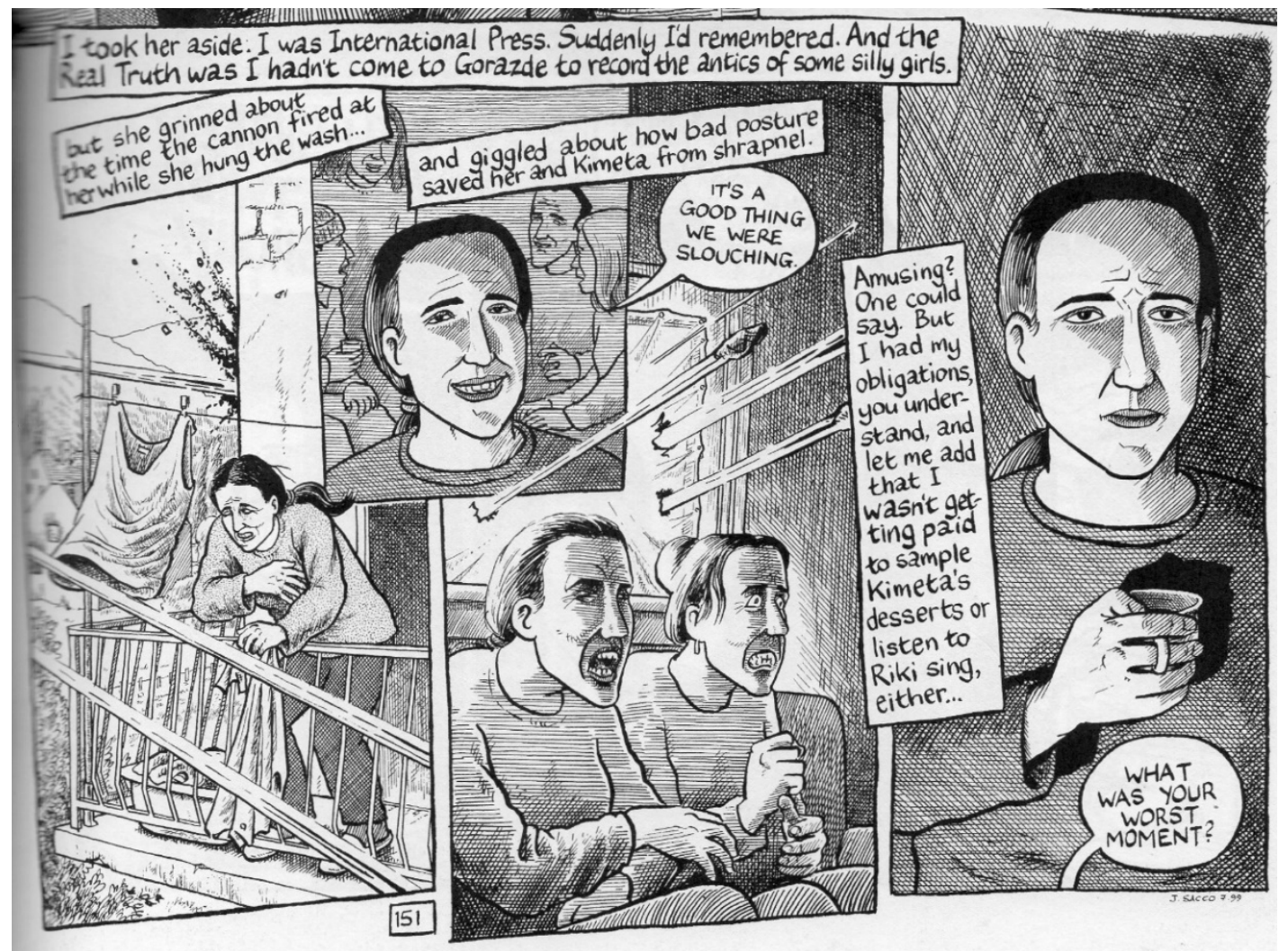

Figure 2: Sacco, 2000, p. 151

In this image from the party, Sacco himself employs the same device as Sabina, using words like "antics," "amusing," "clowning" (p. 151), and "silly" to downplay the seriousness of her trauma. His capitalization of the $\mathrm{R}$ and $\mathrm{T}$ act ironically, an effect heightened by Sabina's subsequent casual bravery. She uses the mundane and matter-of-fact effects of the everyday as a source of humour, grinning at the juxtaposition of cannons and laundry, and giggling at the affiliation of bad posture and shrapnel (p. 151). Andrea Lunsford and Adam Rosenblatt argue that Sacco's entire project is to "restore voice" to victims of trauma, to end silences around war (2011, p. 142). Consequently, Sacco does not appreciate Sabina's levity: "Amusing? One could say. I had my obligations you understand ..." he says before asking for the worst moment she experienced (Sacco, 2000, p. 151), appearing to conflate that with the Real Truth. The brutal plainness of his question wipes the grin off Sabina's face and temporarily silences her (2000, p. 151-2). When she resumes talking, she describes, without any humour this time, the horrors of the war (p. 152).

Veena Das notices a similar pattern in the reminiscences of people who suffered the Partition, suggesting that everyday things gain new value in post-traumatic conditions:

"In everyday conversations of the generation that left Lahore, references to the puris (fried bread) and lassi (yoghurt drink) of Lahore, the zari (brocade) embroidery, the sweetness and freshness of vegetables, the contributions of the Lahore Government College to intellectual life, shopping in the Anar Kali Bazaar, and the myths of Hira Mandi were made liberally. Yet any spontaneous reference to atrocities done, witnessed, or suffered during the partition was not allowed to surface." (Das, 2007, p. 80)

Das's litany of everyday things, food and clothes, shopping (i.e., the acquiring of new things) and stories are what occupy the "silly" girls of Goražde. To Sacco, these acts of deliberate downplaying, 
forgetting, and ignoring are problematic; but the testimonies of his interviewees and Das' may owe more to Marc Augé's prescription that forgetting and restoring "faith in the everyday" are essential to overcoming trauma, as is "mastery over time" (2004, p. 88).

Margaret Gibson proposes the notion of "melancholy objects" that mediate mourning, temporally-invested: "Keeping objects is a way of reclaiming and rehousing (making homely) the remains of a life now gone" (2004, p. 297). In Goražde, it is the everyday life which has been demolished along with the home it inhabited that is being mourned. In this context, it may be suggested that both Edin and the "silly" girls and boys of Goražde are participating in a similar project: re-collecting and "making homely" their post-traumatic selves, using clothes and houses to mourn and to rebuild. Houses, as "spaces for everyday, routine activities" (Moran, 2006, p. 38), may take on the role of surrogate selves, demonstrating identity and history, but also eliding over the ruptures created by trauma, changing the register of testifying from enormity to commonplace.

In Safe Area Goražde, Sacco's efforts to create a cohesive narrative of the "Real Truth" are confounded by instances where the "real" and the "truth" work at cross-purposes. The very everyday clothes and homes that lend the narrative and the subjects spatial and temporal particularity, are, in the aftermath of trauma, equally adept at obfuscation and deflection, at taking on subjecthood when the human subject wishes for silence, and at mediating efforts to recollect and rehabilitate the self. Houses often form the nucleus of this mourning, coming to stand in as containers of past and future selves and routines; clothes -smaller, mobile, changeable containers - gain currency they may lack in less uncertain times, and may come to stand for a hopeful future. If trauma is a rupture in identity, it is here a temporal one, "stalling" the movement to a post-traumatic future. Like the blockades of Goražde, it keeps the subject suspended, and as with the blockade, it is things that first begin to traverse it, so the identitynarrative may become jointed and the subject can "get on with things."

Notes

1 "Puffs, Powders, Patches, Bibles, Billet-doux" (Pope I.ix.4)

\section{References}

Bate, J. (1999). Shakespeare and original genius. In P. Murray (Ed.), Genius - The History of an Idea. New York: Basil Blackwell. 76-97

Adams, J. (2006). Troubled spaces: Domestic space in graphic novels. In G. Smyth \& J. Croft (Eds.), Our house: Representations of domestic space in modern culture (161-174). Amsterdam: Rodopi.

Augé, M. (2004). Oblivion. Trans. Marjolijn de Jager. Minneapolis: University of Minnesota Press.

Baxter, C. (1997). Talking forks: Fiction and the inner life of objects. In Burning down the house: Essays on fiction $\left(2^{\text {nd }}\right.$ ed) (63-86). Saint Paul, Minnesota: Graywolf Press.

Brister, R. (2014). Sounding the occupation: Joe Sacco's Palestine and the uses of graphic narrative for (post)colonial critique. ariel: A review of international English literature, 45(1-2), 103-129. Retrieved from https://muse.jhu.edu/article/552552/summary

Crehan, S. "The rape of the lock" and the economy of "trivial things", Eighteenth-century studies, 31(1), 4568. Retrieved from https://www.jstor.org/stable/30053644

Csikszentmihalyi, M., \& Rochberg-Halton, E. (1981). The meaning of things: Domestic symbols and the self. Cambridge: Cambridge University Press. 
Das, V. (2007). Life and words: Violence and the descent into the ordinary. Berkeley: University of California Press.

de Grazia, M. (1996). The ideology of superfluous things: King Lear as period piece. In M. de Grazia, M. Quilligan, \& P. Stallybrass (Eds.), Subject and object in renaissance culture (17-42). Cambridge: Cambridge University Press.

Gibson, M. (2004). "Melancholy objects." Mortality. 9 (4), 285-299. Retrieved from: http://dx.doi.org/10.108o/13576270412331329812

Hoskins, J. (1998). Biographical objects: How things tell the stories of people's lives. New York: Routledge.

Jones, A. R. \& Stallybrass, P. (2000). Renaissance clothing and the materials of memory. Cambridge: Cambridge University Press, 2000.

Luckhurst, R. (2008). The trauma question. Abingdon: Routledge.

Lunsford, A. A., \& Rosenblatt, A. (2011). "Down a road and into awful silence": Graphic listening in Joe Sacco's comics journalism. In C. Glenn and K. Ratcliffe (Eds.) Silence and listening as rhetorical arts (130-147). Carbondale: Southern Illinois University Press.

Miller, D., \& Woodward, S. (2012). Blue jeans: The art of the ordinary. Berkeley: University of California Press.

Moran, J. (2005). Reading the Everyday. Abingdon: Routledge.

Moran, J. (2006). Houses, habit and memory. In G. Smyth \& J. Croft (Eds.), Our house: Representations of domestic space in modern culture (27-42). Amsterdam: Rodopi.

Pearce, S. M. (1994). Thinking about things. In S. M. Pearce (Ed.) Interpreting objects and collections (125132). New York: Routledge.

Pope, Alexander (1712). The rape of the lock. In H. W. Boynton (Ed.) The complete poetical works. Boston and New York: Houghton Mifflin, 1903. Retrieved from http://www.bartleby.com/203/

Sacco, J. (2000). Safe area Goražde (UK ed.). London: Jonathan Cape.

Sacco, J. (2004). “Underground(s): Robert Williams' presentation from 2003 UF comics conference.” ImageTexT: Interdisciplinary comics studies. 1 (1). Retrieved from http://www.english.ufl.edu/imagetext/archives/vı_1/sacco/

Tilley, C. (2006). Objectification. In C. Tilley, W. Keane, S. Kuechler, M. Rowlands \& P. Spyer (Eds.) A handbook of material culture (6o-73). New Delhi: Sage.

Weiss, G. (1999). Body images: Embodiment as intercorporeality. New York: Routledge.

Shalini Deepa Srinivasan is a PhD candidate at the Department of English, University of Hyderabad. Her areas of interest include comics, children's literature, and nonsense verse. 